\title{
Analisis pengaruh pertumbuhan ekonomi, investasi, belanja daerah, inflasi dan upah terhadap kesempatan kerja di Provinsi Jambi
}

\author{
*Deyana Desideria; Purwaka Hari Prihanto; Hardiani
}

Prodi Ekonomi Pembangunan, Fakultas Ekonomi dan Bisnis, Universitas Jambi

*E-mail Korespondensi: deyanadesideria2@gmail.com_

\begin{abstract}
The purpose of this research were to analyze the economic growth, investation, government expenditure, inflation, and wage the employment of Jambi Province. This research used ordinary least squares. The $F$ test indicated that simultaneously the variables of the economic growth, investation, government expenditure, inflation, and wage significantly affected the employment of Jambi Province. While T test revealed that partially investation, government expenditure, and wage affected the employment of Jambi Province. Meanwhile, the variables of economic growth and inflation insignificant to the employment of Jambi Province.
\end{abstract}

Keywords: Employmen Oppotunity, Investation, Government Expendicture, Wage.

\begin{abstract}
Abstrak
Tujuan penelitian untuk mengetahui dan menganalisis bagaimana perkembangan kesempatan kerja, pertumbuhan ekonomi, investasi, belanja daerah, inflasi dan upah di Provinsi Jambi periode tahun 2000-2016. Alat analisis yang digunakan dalam penelitian ini adalah regresi linear berganda. Berdasarkan hasil uji $\mathrm{F}$ menunjukkan bahwa secara simultan variabel bebas Pengaruh Pertumbuhan Ekonomi, Investasi, Belanja Daerah, Inflasi dan Upah berpengaruh signifikan terhadap kesempatan kerja. Sementara itu, hasil uji $\mathrm{T}$ menunjukkan bahwa investasi, belanja daerah dan upah berpengaruh signifikan terhadap kesempatan kerja Provinsi Jambi. Sedangkan pertumbuhan ekonomi dan inflasi tidak berpengaruh signifikan terhadap kesempatan kerja Provinsi Jambi.
\end{abstract}

Kata Kunci: Kesempatan Kerja, Investasi, Belanja Daerah, Upah.

\section{PENDAHULUAN}

Pasca berakhirnya krisis moneter pada tahun 1998, Indonesia mulai berbenah memperbaiki keadaan ekonominya begitu pula yang terjadi di Provinsi Jambi. Pasca krisis moneter yang terjadi pada tahun 1998 banyak permasalahan sosila yang terjadi di Indonesia salah satunya adalah masalah ketenagakerjaan terkhusus adalah pengangguran. Pengangguran disebabkan karena masih minimnya kesempatan kerja yang tersedia.

Kesempatan kerja menjadi salah satu indikator pembangunan ekonomi. Ketika kesempatan kerja tinggi, maka bisa disimpulkan bahwa pengangguran akan semakin rendah dan ini akan berdampak langsung terhadap kesejahteraan masyarakat. Kesempatan kerja menjadi penting bagi masyarakat sebagai sumber kehidupan untuk memenuhi kebutuhan hidupnya sehari-hari.

Permasalahan kesempatan kerja bukan hanya tentang ketersediaan lapangan kerja bagi angkatan kerja, tetapi juga apakah dapat lapangan kerja yang ada cukup 
mampu memberi timbak balik yang cukup bagi para pekerja. Dengan adanya ketersediaan lapangan kerja yang memadai tentu akan mempercepat proses pembangunan ekonomi apalagi disertai dengan produktivitas yang tinggi. Suatu peluang untuk mendapatkan pekerjaan diberbagai sektor ekonomi disebut dengan kesempatan kerja. Terdapat beberapa faktor yang dapat mempengaruhi kesempatan kerja. Diantara faktor-faktor yang mempengaruhi kesempatan kerja tersebut adalah pertumbuhan ekonomi, investasi, dan angkatan kerja.

Kesempatan kerja adalah banyaknya orang atau tenaga kerja yang dapat terserap untuk bekerja pada suatu perusahaan atau suatu instansi, kesempatan kerja ini akan menyerap semua tenaga kerja yang tersedia apabila lapangan pekerjaan yang tersedia mencukupi atau seimbang dengan banyaknya tenaga kerja yang tersedia. Data kesempatan kerja dapat dilihat dari banyaknya jumlah penduduk 15 tahun ke atas yang bekerja (Tambunan, 2001).

Selama periode tahun 2000-2016 pertumbuhan kesempatan kerja di Provinsi Jambi bersifat fluktuatif. Pada periode tahun 2000-2016 rata-rata pertumbuhan kesempatan kerja di Provinsi Jambi adalah 3,1 persen dengan rata-rata jumlah penduduk bekerja setiap tahunnya sebesar 1.262.804 jiwa. Pada tahun 2014 penduduk yang bekerja di Provinsi Jambi adalah sebesar 1.491.038 jiwa. Jumlah penduduk yang bekerja pada tahun 2015 adalah sebesar 1.550.403 jiwa atau tumbuh sebesar 3,98\% dari tahun sebelumnya. Pada tahun 2016 jumlah penduduk yang bekerja adalah sebesar 1.624.522 jiwa atau kembali mengalami peningkatan dari tahun sebelumnya sebesar 4,78\%.

Dalam beberapa tahun terakhir pertumbuhan ekonomi Provinsi Jambi cukup tinggi, tetapi pertumbuhan yang tinggi tersebut belum mampu menyerap tenaga kerja secara maksimal. Pada umumnya, jika terjadi pertumbuhan ekonomi maka akan terbuka kesempatan kerja baru sehingga mampu mengurangi jumlah pengangguran yang ada. Pertumbuhan ekonomi Provinsi Jambi setiap tahunnya tumbuh secara positif walaupun masih berfluktuatif. Pertumbuhan ekonomi Provinsi Jambi pada periode tahun 20002016 rata-rata tumbuh sebesar 6,24\% setiap tahunnya. Rata-rata pertumbuhan ekonomi tersebut tergolong cukup tinggi bila dibandingkan dengan pertumbuhan ekonomi Indonesia yang hanya tumbuh sebesar 5,33\% setiap tahunnya pada periode yang sama. Pada tahun 2014 pertumbuhan ekonomi Provinsi Jambi berada pada kisaran angka 7,76\%. Namun, pada tahun 2015 pertumbuhan ekonomi Provinsi Jambi sedikit mengalami perlambatan. Pertumbuhan ekonomi Provinsi Jambi pada tahun 2015 hanya tumbuh sebesar 4,21\% hal ini berarti pertumbuhan ekonomi Provinsi Jambi mengalami penurunan dari tahun sebelumnya sebesar 3,14\%. Pada tahun 2016 pertumbuhan ekonomi Provinsi Jambi meningkat lagi, namun tidak cukup signifikan. Ekonomi Provinsi Jambi pada tahun 2016 hanya tumbuh sebesar 4,37\%. Namun, pertumbuhan ekonomi yang cukup tinggi ini masih belum maksimal dalam meningkatkan kesempatan kerja hal tersebut terlihat dari masih cukup tingginya tingkat pengangguran di Provinsi Jambi.

Menurut Jhingan (2004) pertumbuhan ekonomi yang pesat mendorong penyediaan berbagai sarana dan prasarana perekonomian yang dibutuhkan untuk mempercetpat pembangunan ekonomi. Indikator pembangunan ekonomi suatu negara terletak pada pertumbuhan ekonomi dan kesempatan kerja. Sumber daya manusia merupakan faktor terpenting dalam pertumbuhan ekonomi. Pertumbuhan ekonomi tidak semata- mata tergantung pada sumber daya manusia saja, tetapi lebih menekankan pada efisiensi mereka.

Faktor selanjutnya yang menjadi penentu terciptanya kesempatan kerja adalah investasi. Investasi berpengaruh besar terhadap kesempatan kerja dan pendapatan. 
Besarnya nilai investasi akan menentukan besarnya permintaan tenaga kerja, semakin besar investasi maka semakin besar pula tambahan penggunaan tenaga kerja. Untuk perkembangan sektor industri perlu adanya investasi yang memadai agar dalam mengembangkan sektor industri dapat berjalan sesuai yang diinginkan. Usaha akumulasi modal dapat melalui kegiatan investasi yang akan menggerakkan perekonomian melalui mekanisme permintaan agregat, dimana akan meningkatkan usaha produksi dan pada akhimya akan mampu meningkatkan permintaan tenaga kerja (Sukirno, 2010).

Berdasarkan data dari Badan Pusat Statistik (2018), jumah investasi di Provinsi Jambi beberapa tahun terakhir selalu mengalami peningkatan yang positif dalam setiap tahunnya. Pada tahun 2014 nilai total investasi Provinsi Jambi adalah sebesar 39.944.024 juta rupiah dan kembali meningkat pada tahun 2015 menjadi sebesar 46.886.547 juta rupiah. Pada tahun 2016 nilai total investasi pun mengalami peningkatan menjadi 52.782.394 atau tumbuh sebesar 12,57\% dari tahun sebelumnya.

Dengan menigkatnya jumlah investasi disuatu perekonomian diharapkan akan membuka banyak kesempatan kerja baru bagi masyarakat. Namun investasi dipengaruhi oleh suku bunga bank. Untuk mendorong investasi diperlukan suku bunga yang rendah sehingga pengusaha menginvestasikan modalnya ke sektor perekonomian. Dengan adanya penanaman modal yang dilakukan pihak swasta baik yang datang dari luar negeri maupun dalam negeri, diharapkan dapat memacu ekonomi dan menciptakan multiplier effect, dimana kegiatan tersebut akan merangsang kegiatan-kegiatan ekonomi lainnya dan pada akhirnya akan memperluas kesempatan kerja dan meringankan masyarakat (Nainggolan, 2009).

Belanja daerah, atau yang dikenal dengan pengeluaran pemerintah daerah dalam Anggaran Pendapatan dan Belanja Daerah (APBD), merupakan salah satu faktor pendorong pertumbuhan ekonomi daerah. Karena itu, belanja daerah dikenal sebagai salah satu instrumen kebijakan fiskal yang dilakukan pemerintah (pemerintah daerah), di samping pos pendapatan pemerintah daerah. Semakin besar belanja daerah diharapkan akan makin meningkatkan kegiatan perekonomian daerah (Kairupan, 2013). Dengan meningkatnya pertumbuhan ekonomi di daerah nantinya diharapkan dapat meningkatkan terjadinya permintaan tenaga kerja sehingga terbuka kesempatan kerja baru bagi masyarakat.

Belanja daerah yang dikeluarkan oleh pemerintah Provinsi Jambi selalu berubah setiap tahunnya. Berdasarkan data yang dihimpun dari Badan Pusat Statistik (2018), pada tahun 2014 realisasi belanja daerah yang dikeluarkan oleh pemerintah Provinsi Jambi adalah sebesar 3.204.632 juta rupiah. Kemudian pada tahun 2015 belanja daerah di Provinsi Jambi adalah sebesar 3.425.566 juta rupiah atau meningkat sebesar 6,89\% dari tahun sebelumnya. Sementara itu, pada tahun 2016 belanja daerah yang dikeluarkan oleh pemerintah Provinsi Jambi mengalami penurunan sebesar 3,83\% menjadi 3.294.484 juta rupiah. Dengan dikeluarkannya belanja daerah oleh Pemerintah Provinsi Jambi diharapkan dapat membantu mendorong tumbuhnya laju perekonomian di Provinsi Jambi.

Permasalah dalam pertumbuhan ekonomi dan ketenagakerjaan yang selanjutnya adalah inflasi. Inflasi merupakan peristiwa moneter yang sangat penting hampir diseluruh negara. Dengan naiknya permintaan agregat, berdasarkan teori permintaan, permintaan akan naik, kemudian harga akan naik pula. Dengan tingginya harga maka untuk memenuhi permintaan tersebut produsen meningkatkan kapasitas produksinya dengan menambah tenaga kerja. Dengan begitu banyak perusahaan yang akan mengurangi tenaga kerja. Bila tingkat inflasi tinggi, dapat menyebabkan angka 
pengangguran tinggi, ini berarti perkembangan kesempatan kerja menjadi semakin mengecil atau dengan kata lain jumlah tenaga kerja yang diserap juga akan kecil.

Inflasi Provinsi Jambi dihitung hanya di dua kabupaten/kota yaitu, Kabupaten Muaro Bungo dan Kota Jambi. Untuk data di dalam penelitian ini data inflasi yang digunakan adalah data inflasi Kota Jambi. Menurut data BPS (2018) inflasi di Kota Jambi bergerak fluktuatif setiap tahunnya. Pada tahun 2014 inflasi di Kota Jambi adalah sebesar 7,59\% kemudian pada tahun 2015 inflasi di Kota Jambi 5,67\%. Kemudian pada tahun 2016 inflasi di Kota Jambi adalah sebesar 8,72\%. Dari data tersebut dapat dilihat bahwa inflasi yang terjadi tergolong dalam inflasi yang rendah namun apabila dibandingkan kota di provinsi lain masih tergolong tinggi.

Dalam permasalahan mengenai penetapan upah ini sangat diperlukannya campur tangan pemerintah. Hal tersebut dilakukan untuk mengatasi perbedaan pendapat mengenai upah antara pengusaha dan pekerja. Peningkatan pendapatan masyarakat secara tidak langsung akan meningkatkan permintaan barang dan jasa yang nantinya akan mempengaruhi dan mendorong perusahaan-perusahaan untuk terus berkembang.

Menurut data yang di dapat dari Kementrian Ketenagakerjaan biasanya upah selalu mengalami kenaikan setiap tahunnya, begitupun upah minimum yang ditetapkan pemerintah Provinsi Jambi setiap tahunnya selalu mengalami peningkatan. Pada tahun 2014 upah minimum Provinsi Jambi ditetapkan sebesar Rp. 1.502.300 kemudian pada tahun 2015 pemerintah Provinsi Jambi kembali menaikkan upah minimum menjadi sebesar Rp. 1.710.000 atau terjadi peningkatan sebesar Rp. 210.000. Selanjutnya pada tahun 2016 upah minimum Provinsi jambi kembali mengalami peningkatan menjadi Rp. 1.906.650.

Berdasarkan fenomena pada latar belakang masalah yang telah diuraikan di atas penulis dapat merumuskan permasalahan sebagai berikut: 1) Bagaimana perkembangan kesempatan kerja, pertumbuhan ekonomi, investasi, belanja daerah, inflasi dan upah di Provinsi Jambi Periode tahun 2000-2016; 2) Bagaimana elastisitas kesempatan kerja di Provinsi Jambi periode tahun 2000-2016; 3) Bagaimana pengaruh pertumbuhan ekonomi, investasi, inflasi, belanja daerah dan upah terhadap kesempatan kerja di Provinsi Jambi pada periode tahun 2000-2016. Tujuan dari penelitian berdasarkan latar belakang di atas adalah sebagai berikut: 1) Mengetahui dan menganalisis bagaimana perkembangan kesempatan kerja, pertumbuhan ekonomi, investasi, belanja daerah, inflasi dan upah di Provinsi Jambi Periode tahun 2000-2016; 2) Mengetahui dan menganalisis bagaimana elastisitas kesempatan kerja di Provinsi Jambi periode tahun 2000-2016; 3) Mengetahui dan menganalisis bagaimana pengaruh pertumbuhan ekonomi, investasi, belanja daerah, inflasi, dan upah terhadap kesempatan kerja di Provinsi Jambi periode tahun 2000-2016. Berdasarkan uraian di atas penulis bermaksud untuk melakukan penelitian tentang "Analisis Pengaruh Pertumbuhan Ekonomi, Investasi, Belanja Daerah, Inflasi dan Upah Terhadap Kesempatan Kerja di Provinsi Jambi”.

\section{METODE}

Metode yang digunakan dalam penelitian ini adalah metode analisis data sekunder. Data sekunder yang digunakan dalam penelitian ini adalah data time series periode 2000-2016. Analisis data sekunder adalah analisis yang dilakukan dengan menggunakan data yang terlebih dahulu dikumpulkan dan oleh instansi terkait.

Metode yang digunakan untuk mengetahui Pengaruh Pertumbuhan Ekonomi, Investasi, Belanja Daerah, Inflasi dan Upah Terhadap Kesempatan Kerja di Provinsi Jambi digunakan analisis regresi linear berganda. Model persamaannya adalah sebagai 
berikut:

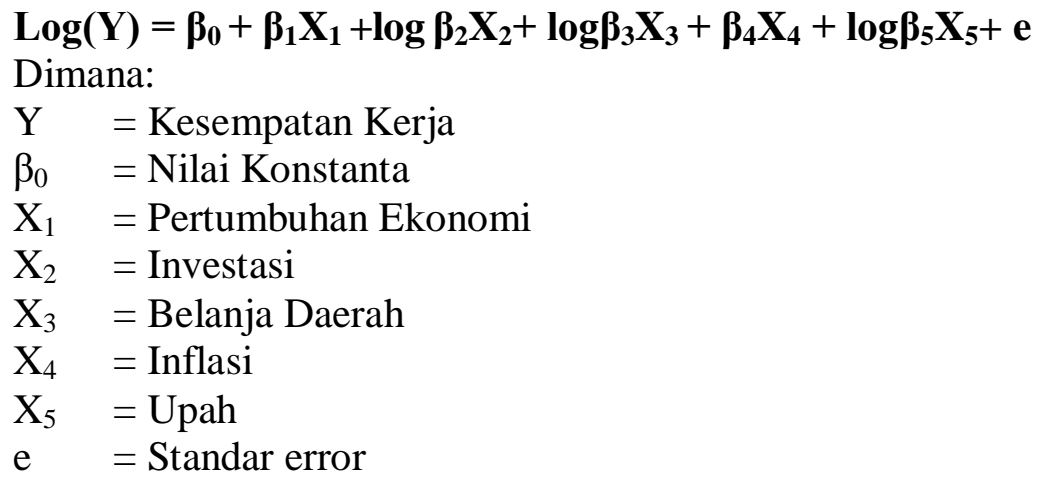

Disamping itu juga dilakukan pengujian hipotesis yakni uji F, uji T, uji koefisian dterminasi $\mathrm{R}^{2}$. Uji statistik $\mathrm{F}$ pada dasarnya menunjukkan apakah semua variabel independen atau bebas yang dimasukkan dalam model mempunyai pengaruh secara bersama-sama terhadap variabel dependen atau terikat. Uji $t$ dilakukan untuk mengetahui pengaruh dari masing-masing variabel independen terhadap variabel dependen. Koefisien determinasi $\left(\mathrm{R}^{2}\right)$ mengukur seberapa jauh kemampuan model dalam menerangkan variasi variabel dependen. Nilai koefisien determinasi adalah antara nol dan satu.

Dalam analisis regresi linear berganda ini uji asumsi klasik yang dihitung menggunakan program eviews antara lain: (1) Uji multikolinieritas cara mendeteksinya adalah dengan melihat nilai VIF, apabila nilainya $<10$ maka data tersebut tidak terjadi multikolinieritas; (2) Uji autokorelasi, cara mendeteksinya adalah dengan menggunakan Durbin Watson test; (3) Uji heterokedastisitas, cara mendeteksinya salah satunya adalah menggunakan metode Uji Breusch Pagan (Ghazali, 2005).

\section{HASIL DAN PEMBAHASAN}

\section{Perkembangan kesempatan kerja Provinsi Jambi}

Tenaga kerja merupakan faktor produksi yang sangat penting di dalam kegiatan produksi barang dan jasa. Tenaga kerja memiliki keistimewaan tersendiri dibandingkan dengan faktor produksi lainnya. Salah satu yang menjadi tolak ukur keberhasilan pembangunan ekonomi suatu negara atau daerah adalah bagimana keadaan ketenagakerjaanya. Salah satu yang menjadi perhatian dalam masalah ketenagakerjaan ini adalah masalah kesempatan kerja.

Kesempatan kerja dalam hal ini merupakan angkatan kerja yang berusia 15 tahun ke atas yang bekerja menurut lapangan usaha. Atau juga dapat dikatakan kesempatan kerja merupakan suatu keadaan yang mencerminkan seberapa jumlah dari total angkatan kerja yang dapat diserap atau ikut serta secara aktif dalam kegiatan perekonomian. Selain itu kesempatan kerja juga dapat diartikan sebagai jumlah penduduk yang bekerja atau orang yang sudah memperoleh pekerjaan, semakin banyak orang yang bekerja semakin luas kesempatan kerja.

Untuk mengetahui bagaimana gambaran mengenai kesempatan kerja adalah dengan menggunakan data sensus penduduk, Survei Angkatan Kerja Nasional (SAKERNAS) dimana penduduk yang bekerja dalam suatu sektor perekonomian merupakan cerminan kesempatan kerja yang tersedia dalam sektor perekonomian tersebut. Berdasarkan penjelasan di atas dapat disimpulkan bahwa kesempatan kerja ditunjukkan oleh orang-orang yang sudah bekerja menempati lapangan usaha yang tersedia. 
Tabel 1. Penduduk 15 Tahun keatas yang bekerja Provinsi Jambi Tahun 2000-2016

\begin{tabular}{ccc}
\hline Tahun & $\begin{array}{c}\text { Penduduk Bekerja } \\
(\text { Jiwa) }\end{array}$ & Perkembangan $(\boldsymbol{\%})$ \\
\hline 2000 & 1004844 & \\
2001 & 1013666 & 0.88 \\
2002 & 1094331 & 7.96 \\
2003 & 1101833 & 0.69 \\
2004 & 1137460 & 3.23 \\
2005 & 1113150 & -2.14 \\
2006 & 1103386 & -0.88 \\
2007 & 1146851 & 3.94 \\
2008 & 1224483 & 6.77 \\
2009 & 1260592 & 2.95 \\
2010 & 1360022 & 7.89 \\
2011 & 1434998 & 5.51 \\
2012 & 1423624 & -0.79 \\
2013 & 1382471 & -2.89 \\
2014 & 1491038 & 7.85 \\
2015 & 1550403 & 3.98 \\
2016 & 1624522 & 4.78 \\
\hline
\end{tabular}

Sumber: BPS Provinsi Jambi, 2018 (diolah)

Berdasarkan pada tabel diatas terlihat bahwa perkembangan kesempatan kerja di Provinsi Jambi selama tahun 2002-2016 mengalami fluktuasi. Perkembangan kesempatan kerja yang paling tinggi terjadi pada tahun 2002 sebesar 7.96 persen. Perkembangan kesempatan kerja yang tertinggi kedua terjadi pada tahun 2010 yaitu sebesar 7.89 persen. Perkembangan kesempatan kerja yang ketiga terjadi pada tahun 2014 yaitu sebesar 7.85 persen. Perkembangan kesempatan kerja yang paling rendah terjadi pada tahun 2013 yiatu sebesar -2.89 persen. Perkembangan kesempatan kerja yang terendah kedua terjadi pada tahun 2005 yaitu sebesar -2.14 persen. Rata-rata perkembangan kesempatan kerja di Provinsi Jambi dari tahun 2002-2016 yaitu sebesar 3,11 persen pertahunnya.

\section{Pertumbuhan ekonomi di Provinsi Jambi}

Pembangunan ekonomi suatu daerah atau negara biasanya bertujuan untuk mendorong pertumbuhan ekonomi. Pertumbuhan ekonomi dapat digunakan sebagai indikator kesejahteraan penduduk suatu negara, semakin tinggi pertumbuhan ekonominya maka sektor riil di dalam negara tersebut juga mengalami peningkatan. Pertumbuhan ekonomi yang baik adalah pertumbuhan ekonomi yang mampu menyerap tenaga kerja. Pertumbuhan sektor riil tersebut nantinya diharapkan mampu meningkatkan tkesempatan kerja di Provinsi Jambi. Untuk melihat bagaimana perkembangan pertumbuhan ekonomi Provinsi Jambi dapat kita lihat pada tabel 5.2 berikut ini: 
Tabel 2. Pertumbuhan ekonomi Provinsi Jambi Tahun 2000-2016

\begin{tabular}{cc}
\hline Tahun & Pertumbuhan Ekonomi $(\%)$ \\
\hline 2000 & 5.33 \\
2001 & 5.87 \\
2002 & 5.86 \\
2003 & 5.00 \\
2004 & 5.38 \\
2005 & 5.57 \\
2006 & 5.89 \\
2007 & 7.16 \\
2008 & 7.16 \\
2009 & 6.39 \\
2010 & 7.35 \\
2011 & 8.54 \\
2012 & 7.03 \\
2013 & 7.07 \\
2014 & 7.76 \\
2015 & 4.21 \\
2016 & 4.37 \\
\hline Rata-rata & $\mathbf{6 . 2 3}$ \\
\hline
\end{tabular}

Sumber: BPS Provinsi Jambi, 2018 (diolah)

Pertumbuhan sektor riil tersebut nantinya diharapkan mampu meningkatkan kesempatan kerja di Provinsi Jambi. Provinsi Jambi merupakan Provinsi yang memiliki sumber daya alam yang cukup banyak untuk dimanfaatkan. Pertumbuhan ekonomi Provinsi Jambi biasanya didominasi oleh sektor pertanian dan sektor perkebunan. Hal ini dapat terlihat dari banyaknya lahan pertanian perkebunan yang terdapat hampir diseluruh Kabupaten/Kota di Provinsi Jambi. Sektor yang menjadi penyumbang terbesar kedua pertumbuhan ekonomi di Provinsi Jambi adalah sektor pertambangan dan penggalian. Kemudian ada beberapa sektor yang menjadi penyumbang cukup besar pertumbuhan ekonomi di Provinsi Jambi adalah sektor perdagangan dan perhotelan.

Berdasarkan tabel 5.2 pertumbuhan ekonomi Provinsi Jambi pada periode tahun 2000-2016 selalu tumbuh positif namun masih bersifat fluktuatif. Pertumbuhan ekonomi Provinsi Jambi tertinggi terjadi pada tahun 2011 dengan pertumbuhan sebesar 8,54\%. Pertumbuhan ekonomi kedua tertinggi terjadi pada tahun 2014 dengan pertumbuhan sebesar 7,76\%. Sedangkan pertumbuhan ekonomi terendah terjadi pada tahun 2015 dengan pertumbuhan sebesar 4,21\%. Rata-rata pertumbuhan ekonomi Provinsi Jambi tumbuh sebesar $6,23 \%$ setiap tahunnya selama periode tersebut.

\section{Perkembangan investasi Provinsi Jambi Tahun 2000-2016}

Investasi merupakan salah satu faktor pendukung yang mempengaruhi kegiatan pembangunan nasional. Investai memiliki peranan tersendiri di dalam kegiatan perekonomian khususnya di dalam masalah ketenagakerjaan. Di Indonesia, investasi dibedakan atas dua, pertama investasi yang dilakukan oleh pihak penanaman modal dalam negeri (PMDN) dan penanaman modal asing (PMA). Investasi di Provinsi Jambi terus mengalami peningkatan setiap tahunnya. Investasi sangat diperlukan di dalam sebuah perekonomian untuk mendorong pertumbuhan ekonomi di suatu negara maupun di daerah. Dengan demikian akan tercipta lapangan kerja baru sehingg mampu 
mengurangi jumlah pengangguran yang ada pada suatu wilayah perekonomian.

Tabel 3. Investasi Provinsi Jambi Tahun 2000-2016 (Ribu Rupiah)

\begin{tabular}{ccc}
\hline Tahun & Investasi & Pertumbuhan $(\%)$ \\
\hline 2000 & 8033728 & \\
2001 & 8076957 & 0.54 \\
2002 & 8865781 & 9.77 \\
2003 & 8549407 & -3.57 \\
2004 & 9797734 & 14.14 \\
2005 & 9199192 & -5.73 \\
2006 & 10315485 & -88.79 \\
2007 & 10364966 & 13.56 \\
2008 & 10820760 & 654.47 \\
2009 & 9866043 & 104.87 \\
2010 & 11616881 & -35.84 \\
2011 & 19197499 & 28.24 \\
2012 & 27384363 & 83.82 \\
2013 & 34325653 & 25.35 \\
2014 & 39944024 & 16.37 \\
2015 & 46224578 & 17.38 \\
2016 & 52782394 & 12.57 \\
\hline
\end{tabular}

Sumber: BPS Provinsi Jambi, 2018 (diolah)

Pada Tabel 3, terlihat bagaimana perkembangan nilai investasi di Provinsi Jambi selama periode tahun 2000-2016. Pertumbuhan investasi di Provinsi Jambi terjadi pada tahun 2011 yang tumbuh sebesar 65,26\% dari tahun sebelumnya. Pertumbuhan investasi kedua tertinggi di Provinsi Jambi terjadi pada tahun 2012 dengan pertumbuhan sebesar 42,65\%. Sementara itu, pertumbuhan investasi terendah terjadi pada tahun 2009 sebesar $-8,82 \%$. Rata-rata pertumbuhan investasi selama periode tersebut adalah $13,79 \%$ setiap tahunnya.

\section{Perkembangan belanja daerah Provinsi Jambi Tahun 2000-2016}

Menurut halim (2003) Belanja daerah adalah pengeluaran yang dilakukan oleh pemerintah daerah untuk melaksanakan wewenang dan tanggung jawab kepada masyarakat dan pemerintah diatasnya. Belanja daerah yang dikeluarkan oleh pemerintah Provinsi Jambi selalu berubah setiap tahunnya. Sementara undang-undang Republik Indonesia nomor 33 tahun 2004 menyatakan bahwa belanja daerah adalah semua kewajiban daerah yang diakui sebagai pengurang nilai kekayaan bersih dalam periode tahun anggaran yang bersangkutan. Sedangkan untuk pembiayaan daerah ialah semua penerimaan yang perlu dibayar kembali dan pengeluaran yang akan diterima kembali baik pada tahun anggaran yang bersangkutan maupun anggaran berikutnya. Alokasi belanja yang dianggarkan pemerintah melalui alokasi belanja modal, dimana belanja ini untuk menggenjot pembangunan serta investasi swasta baik dalam negeri maupun asing. Untuk melihat lebih jelasnya tentang perkembangan belanja daerah di Provinsi Jambi dari tahun 2002-2016 dapat dilihat pada tabel dibawah ini: 
Tabel 4. Belanja daerah Provinsi Jambi Tahun 2000-2016 (Juta Rupiah)

\begin{tabular}{ccc}
\hline Tahun & Belanja Daerah (Juta) & Pertumbuhan $(\boldsymbol{\%})$ \\
\hline 2000 & 107265 & \\
2001 & 238790 & 122.62 \\
2002 & 374520 & 56.84 \\
2003 & 563976 & 50.59 \\
2004 & 587933 & 4.25 \\
2005 & 642833 & 9.34 \\
2006 & 978239 & 52.18 \\
2007 & 1107692 & 13.23 \\
2008 & 1401983 & 26.57 \\
2009 & 1530073 & 9.14 \\
2010 & 1443130 & -5.68 \\
2011 & 1750242 & 21.28 \\
2012 & 2868320 & 63.88 \\
2013 & 3012295 & 5.02 \\
2014 & 3204632 & 6.39 \\
2015 & 3425566 & 6.89 \\
2016 & 3294484 & -3.83 \\
\hline
\end{tabular}

Sumber: BPS Provinsi Jambi, 2018 (diolah)

Pada Tabel 4, terlihat bagaimana perkembangan belanja daerah di Provinsi Jambi selama periode tahun 2000-2016. Pertumbuhan belanja daerah di Provinsi Jambi terjadi pada tahun 2001 yang tumbuh sebesar 122,62\% dari tahun sebelumnya. Pertumbuhan belanja daerah kedua tertinggi di Provinsi Jambi terjadi pada tahun 2012 dengan pertumbuhan sebesar $63,88 \%$. Sementara itu, pertumbuhan belanja daerah terendah terjadi pada tahun 2010 sebesar $-5,68 \%$. Rata-rata pertumbuhan belanja daerah selama periode tersebut adalah $27,42 \%$ setiap tahunnya.

\section{Perkembangan inflasi Provinsi Jambi Tahun 2000-2016}

Dengan adanya kecenderungan bahwa tingkat inflasi dan pengangguran kedudukannya naik (tidak ada trade off) maka menunjukkan bahwa adanya perbedaan dengan kurva philips dimana terjadi trade off antara inflasi yang rendah atau pengangguran yang rendah. Jika tingkat inflasi yang diinginkan adalah rendah, maka akan terjadi tingkat pengangguran yang sangat tinggi. Sebaliknya, jika tingkat inflasi yang diinginkan tinggi, maka akan terjadi tingkat pengangguran yang relatif rendah.

Inflasi merupakan kenaikan harga-harga umum secara berkelanjutan, yang merupakan salah satu variabel ekonomi makro yang penting, karena dapat mempengaruhi kesejahteraan penduduk suatu negara. Inflasi yang tinggi mengimplikasikan penurunan daya beli sehingga kemampuan masyarakat untuk menikmati barang dan jasa semakin berkurang, dengan kata lain kemakmuran berkurang. Sehubungan dengan itu, para pembuat kebijakan di negara-negara seluruh dunia berusaha untuk sebisa mungkin mengendalikan inflasi. Tingkat inflasi mempunyai hubungan positif atau negatif terhadap kesempatan kerja. Apabila tingkat inflasi yang dihitung adalah inflasi yang terjadi pada harga-harga secara umum, maka tingginya tingkat inflasi yang terjadi akan berakibat pada peningkatan pada tingkat 
bunga (pinjaman). Untuk melihat bagaimana keadaan inflasi di Provinsi Jambi pada tabel 5 berikut:

Tabel 5. Inflasi Kota Jambi Tahun 2000-2016

\begin{tabular}{cc}
\hline Tahun & Inflasi $(\boldsymbol{\%})$ \\
\hline 2000 & 1.9 \\
2001 & 0.36 \\
2002 & 1.18 \\
2003 & 1.76 \\
2004 & 1.63 \\
2005 & 0.7 \\
2006 & 2.01 \\
2007 & 1.84 \\
2008 & 0.1 \\
2009 & 0.31 \\
2010 & 1.83 \\
2011 & 0.66 \\
2012 & 0.62 \\
2013 & 0.4 \\
2014 & 2.61 \\
2015 & 1.43 \\
2016 & 0.36 \\
\hline Rata-Rata & $\mathbf{1 . 1 6}$ \\
\hline
\end{tabular}

Sumber: BPS Provinsi Jambi, 2018 (diolah)

Pada Tabel 5, terlihat bagaimana perkembangan nilai inflasi di Provinsi Jambi selama periode tahun 2000-2016. Pertumbuhan inflasi di Provinsi Jambi terjadi pada tahun 2014 yang tumbuh sebesar 2,61\% dari tahun sebelumnya. Pertumbuhan inflasi kedua tertinggi di Provinsi Jambi terjadi pada tahun 2006 dengan pertumbuhan sebesar $2,01 \%$. Sementara itu, pertumbuhan inflasi terendah terjadi pada tahun 2008 sebesar $0,1 \%$. Rata-rata pertumbuhan inflasi selama periode tersebut adalah $1,16 \%$ setiap tahunnya.

\section{Perkembangan upah Provinsi Jambi Tahun 2000-2016}

Sejatinya upah merupakan bayaran yang diterima tenaga kerja yang telah melakukan pekerjaannya. Di Indonesia, tingkat upah biasanya ditetapkan oleh pemerintah, baik pemerintah nasional maupun pemerintah daerah. Hal tersebut dibuat untuk menghindari terjadinya konflik antara pengusaha dan para pekerja.

Peningkatan upah minimum ini sebenarnya dapat meningkatkan kemampuan para pekerja dalam memenuhi kebutuhan hidupnya, namun peningkatan upah minimum yang terlalu cepat dan tinggi berpotensi mengurangi kesempatan kerja, terutama pekerja formal di Provinsi Jambi. Kondisi ini akan menimbulkan dilema bagi Pemerintah Provinsi Jambi. Disatu sisi apakah upah minimum akan terus ditingkatkan yang sebenarnya hanya menguntungkan sebagian kecil pekerja dengan mengorbankan pekerja lainnya di sektor tertentu, atau perhatian difokuskan pada penciptaan kesempatan kerja baru yang ada pada akhirnya meningkatkan kesejahteraan sebagian besar penduduk Provinsi Jambi. Permintaan tenaga kerja merupakan fungsi dari tingkat upah. Semakin tinggi tingkat upah, semakin kecil permintaan pengusaha akan tenaga 
kerja. Kenaikan tingkat upah akan diikuti oleh turunnya jumlah tenaga kerja yang diminta, yang berarti akan menyebabkan bertambahnya jumlah pengangguran. Untuk melihat bagaimana keadaan tingkat upah di Provinsi Jambi pada tabel 5.6 berikut:

Tabel 6. Perkembangan tingkat upah Provinsi Jambi Tahun 2000-2016

\begin{tabular}{ccc}
\hline Tahun & Upah (Rupiah) & Perkembangan Upah (\%) \\
\hline 2000 & 173000 & 41.62 \\
2001 & 245000 & 24.08 \\
2002 & 304000 & 28.29 \\
2003 & 390000 & 8.97 \\
2004 & 425000 & 14.12 \\
2005 & 485000 & 16.08 \\
2006 & 563000 & 16.87 \\
2007 & 658000 & 10.03 \\
2008 & 724000 & 10.50 \\
2009 & 800000 & 12.50 \\
2010 & 900000 & 14.22 \\
2011 & 1028000 & 11.14 \\
2012 & 1142500 & 13.79 \\
2013 & 1300000 & 15.56 \\
2014 & 1502230 & 13.83 \\
2015 & 1710000 & 11.50 \\
2016 & 1906650 & $\mathbf{1 6 . 4 4}$ \\
\hline
\end{tabular}

Sumber: BPS Provinsi Jambi 2018 (diolah)

Berdasarkan Tabel 6, perkembangan tingkat upah Provinsi Jambi pada periode tahun 2000-2016 selalu tumbuh positif namun masih bersifat fluktuatif. Tingkat upah di Provinsi Jambi tertinggi terjadi pada tahun 2001 dengan pertumbuhan sebesar 41,62\%. Perkembangan tingkat upah kedua tertinggi terjadi pada tahun 2003 dengan pertumbuhan sebesar $28,29 \%$. Sedangkan tingkat upah terendah terjadi pada tahun 20104 dengan pertumbuhan sebesar 8,97\%. Rata-rata tingkat upah Provinsi Jambi tumbuh sebesar $16,44 \%$ setiap tahunnya selama periode tersebut.

\section{Elastisitas ksempatan kerja Provinsi Jambi}

Inelastis, jika koefisien elastisitas bernilai kurang dari 1 maka dikategorikan sebagai inelastis yaitu besar jumlah permintaan barang tidak dipengaruhi oleh besar kecilnya harga. Hal ini terjadi apabila harga suatu barang turun namun nilai peningkatan permintaannya lebih sedikit dari nilai penurunan harga.

Elastisitas kesempatan kerja merupakan angka yang menunjukkan tingkat hubungan fungsional antara pertumbuhan kesempatan kerja dengan pertumbuhan ekonomi. Dari tabel di bawah dapat dilihat besarnya elastisitas kesempatan kerja yang ada Provinsi Jambi selama periode tahun 2000-2016 mengalami fluktuasi pada setiap tahunnya. Jika dilihat secara keseluruhan maka besarnya elastisitas kesempatan kerja Provinsi Jambi yaitu sebesar 0,48, dari hasil ini dapat dikatakan bahwa kesempatan kerja bersifat InElastis ( $\mathrm{E}>1$ ). Dengan demikian dapat diketahui bahwa setiap kenaikan PDRB sebesar $1 \%$ maka kesempatan kerja akan bertambah sebesar 0,48\% dari jumlah tenaga kerja yang ada di Provinsi Jambi. Dari hasil perhitungan elastisitas kesempatan 
kerja memberikan pengertian bahwa besarnya kesempatan kerja yang tersedia bukan akibat dari kenaikan pertumbuhan ekonomi. Elastisitas kesempatan kerja bersifat negatif pada tahun 2005, 2006, 2012, dan tahun 2013. Dengan demikian maka tingkat elastisitas kesempatan kerja di Provinsi Jambi sebagai berikut:

Tabel 7. Elastisitas kesempatan kerja Provinsi Jambi Tahun 2000-2016

\begin{tabular}{ccccc}
\hline Tahun & $\begin{array}{c}\text { Pertumbuhan } \\
\text { Kesempatan } \\
\text { Kerja }\end{array}$ & $\begin{array}{c}\text { Pertumbuhan } \\
\text { Ekonomi }\end{array}$ & $\begin{array}{c}\text { Elastisitas } \\
\text { Kesempatan } \\
\text { Kerja }\end{array}$ & $\begin{array}{c}\text { Koefisisen } \\
\text { Elastisitas }\end{array}$ \\
\hline 2000 & 1.25 & 5.33 & 0.23 & Inelastis \\
2001 & 0.88 & 5.87 & 0.15 & Inelastis \\
2002 & 7.96 & 5.86 & 1.36 & Elastis \\
2003 & 0.69 & 5 & 0.14 & Inelastis \\
2004 & 3.23 & 5.38 & 0.60 & Inelastis \\
2005 & -2.14 & 5.57 & -0.38 & Inelastis \\
2006 & -0.88 & 5.89 & -0.15 & Inelastis \\
2007 & 3.94 & 7.16 & 0.55 & Inelastis \\
2008 & 6.77 & 7.16 & 0.95 & Inelastis \\
2009 & 2.95 & 6.39 & 0.46 & Inelastis \\
2010 & 7.89 & 7.35 & 1.07 & Elastis \\
2011 & 5.51 & 8.54 & 0.65 & Inelastis \\
2012 & -0.79 & 7.03 & -0.11 & Inelastis \\
2013 & -2.89 & 7.07 & -0.41 & Inelastis \\
2014 & 7.85 & 7.76 & 1.01 & Elastis \\
2015 & 3.98 & 4.21 & 0.95 & Inelastis \\
2016 & 4.78 & 4.37 & 1.09 & Elastis \\
\hline
\end{tabular}

Sumber: Data diolah 2018

Pengaruh pertumbuhan ekonomi, investasi, belanja daerah, inflasi dan upah terhadap kesempatan kerja Provinsi Jambi Tahun 2000-2016

Data regresi pengaruh pertumbuhan ekonomi, investasi, belanja daerah, inflasi dan upah terhadap kesempatan kerja di Provinsi Jambi tahun 2000 sampai dengan 2016 diperoleh nilai koefisien regresi untuk setiap variabel penelitian dengan persamaan sebagai berikut:

$\mathrm{KK}=10.49691+0.007831 \mathrm{X} 1+0.031975 \log (\mathrm{X} 2)+0.111291 \log (\mathrm{X3})+0.006662 \mathrm{X} 4$ - $0.335768 \log (\mathrm{X} 5)+\mathrm{e}$

Interpretasi hasil regresi pengaruh pertumbuhan ekonomi, investasi, belanja daerah, inflasi dan upah terhadap kesempatan kerja di Provinsi Jambi tahu 2000-2016 adalah sebagai berikut:

\section{Pengaruh pertumbuhan ekonomi terhadap kesempatan kerja Provinsi Jambi}

Berdasarkan hasil analisis dapat dijelaskan bahwa variabel pertumbuhan ekonomi tidak berpengaruh signifikan dengan nilai koefisien sebesar 0.007831 terhadap kesempatan kerja di Provinsi Jambi tahun 2000 sampai 2016.

Hukum Okun dalam Mankiw (2007) yang menyatakan adanya pengaruh negatif antara pengangguran dan GDP riil. Hal tersebut mengindikasikan bahwa jika pertumbuhan ekonomi meningkat maka akan mengurangi pengangguran atau juga dapat dikatakan jika pertumbuhan ekonomi di suatu negara atau daerah meningkat maka 
secara tidak langsung akan terjadi penyerapan tenaga kerja.

Namun di dalam penelitian yang dilakukan oleh Purnama (2015) menyatakan bahwa tidak ada pengaruh signifikan pertumbuhan ekonomi terhadap pengangguran. Hal tersebut mengindikasikan bahwa tidak adanya ketersediaan kesempatan kerja baru bagi masyarakat. Hal ini mungkin terjadi karena tidak meratanya pertumbuhan ekonomi tersebut serta mungkin kesempatan kerja dipengaruhi oleh faktor lain seperti investasi dan yang lainnya. Kemudian, di dalam perekonomian Provinsi Jambi sektor yang menjadi unggulan adalah sektor pertanian dan perkebunan terutama adalah perkebunan kelapa sawit yang tidak begitu banyak membutuhkan jumlah tenaga kerja sehingga pertumbuhan ekonomi yang tinggi pun tidak begitu banyak berpengaruh terhadap peningkatan kesempatan kerja di Provinsi Jambi.

\section{Pengaruh investasi terhadap kesempatan kerja Provinsi Jambi}

Berdasarkan hasil analisis dapat dijelaskan bahwa variabel investasi berpengaruh positif dan signifikan dengan nilai koefisien sebesar 0.031975 terhadap kesempatan kerja di Provinsi Jambi tahun 2000 sampai 2016. Hal ini menunjukkan bahwa pertumbuhan ekonomi mempunyai pengaruh terhadap kesempatan kerja.

Hasil ini sesuai dengan hipotesis penelitian yang menyatakan ada pengaruh dan signifikan investasi terhadap kesempatan kerja di Provinsi Jambi selama tahun 20002016. Artinya apabila terjadi peningkatan terhadap investasi sebesar 1 persen maka akan mengakibatkan kesempatan kerja meningkat sebesar 0.031975 persen. Hal ini sesuai dengan hipotesis yang menyatakan bahwa secara langsung investasi berpengaruh positif dan signifikan terhadap kesempatan kerja. Sejalan dengan pernyataan Sukirno (2010) investasi berpengaruh besar terhadap kesempatan kerja dan pendapatan. Besarnya investasi akan menentukan besarnya permintaan tenaga kerja. Semakin besar investasi maka akan semakin besar pula tambahan penggunaan tenaga kerja. Usaha akumulasi modal dapat melalui kegiatan investasi yang akan menggerakkan perekonomian melalui mekanisme permintaan agregat, dimana akan meingkatkan usaha produksi dan pada akhirnya akan mampu meningkatkan pemintaan tenaga kerja.

\section{Pengaruh belanja daerah terhadap kesempatan kerja Provinsi Jambi}

Berdasarkan hasil analisis dapat dijelaskan bahwa belanja daerah berpengaruh dan signifikan terhadap kesempatan kerja di Provinsi Jambi tahun 2000-2016 dengan nilai koefisien sebesar 0.111291 .

Hasil ini sesuai dengan hipotesis penelitian yang menyatakan ada pengaruh positif dan signifikan belanja daerah terhadap kesempatan kerja di Provinsi Jambi selama tahun 2000-2016. Artinya apabila terjadi peningkatan terhadap belanja daerah sebesar 1 persen maka akan mengakibatkan kesempatan kerja meningkat sebesar 0.111291 persen. Hal ini sesuai dengan hipotesis yang menyatakan bahwa secara langsung investasi berpengaruh positif dan signifikan terhadap kesempatan kerja.

Sejalan dengan penelitian yang dilakukan oleh Sondakh dkk (2017) yang menemukan bahwa alokasi belanja yang dianggarkan pemerintah melalui alokasi belanja modal, dimana belanja ini untuk menggenjot pembangunan serta investasi swasta baik dalam negeri maupun asing mempunyai korelasi atau hubungan saling keterkaitan satu sama lain dengan kesempatan kerja. Dimana berdasarkan hasil penghitungan didapatkan hasil bahwa semakin tinggi tingkat alokasi belanja modal yang dianggarkan dan semakin banyak ketertarikan investasi dari dalam maupun luar negeri akan semakin mengurangi jumlah pengangguran. Adanya pengalokasian belanja modal dari pemerintah yang penggunaannya memang untuk membangun fasilitas publik serta 
memperlancar arus ekonomi serta investasi dari pihak swasta juga akan menggenjot pertumbuhan ekonomi. Tenaga-tenaga kerja yang sebelumnya belum atau tidak menghasilkan akan dapat menghasilkan pendapatan yang kemudian pendapatanpendapatan yang semakin baik ini akan digabungkan untuk melihat seberapa besar pertumbuhan ekonomi yang terjadi.

\section{Pengaruh inflasi terhadap kesempatan kerja Provinsi Jambi}

Berdasarkan hasil analisis dapat dijelaskan bahwa inflasi tidak berpengaruh signifikan terhadap kesempatan kerja di Provinsi Jambi tahun 2000-2016 dengan nilai koefisien sebesar 0.006662. Hasil ini tidak sesuai dengan hipotesis penelitian yang menyatakan ada pengaruh negatif dan signifikan inflasi terhadap ksempatan kerja di Provinsi Jambi. Inflasi berhubungan negatif terhadap kesempatan kerja. Pada saat terjadi inflasi para investor berpikir ulang untuk menanamkan modalnya, karena para investor berpikir akan mengalami kerugian yang disebabkan tingginya modal yang dikeluarkan dibandingkan dengan keuntungan yang didapatakan dan mengurangi penyerapan tenaga kerja yang ada. Apabila inflasi meningkat maka permintaan terhadap produksi barang akan menurun dan kesempatan kerja pasti akan menurun. Dengan demikian tinggi ataupun rendahnya inflasi tidak berpengaruh signifikan terhadap kesempatan kerja.

\section{Pengaruh upah terhadap kesempatan kerja Provinsi Jambi}

Berdasarkan hasil analisis dapat dijelaskan bahwa upah berpengaruh dan signifikan dengan nilai koefisien sebesar -0.335768 terhadap kesempatan kerja di Provinsi Jambi tahun 2000 sampai 2016. Hal ini menunjukkan bahwa upah mempunyai pengaruh terhadap kesempatan kerja.

Hasil ini sesuai dengan hipotesis penelitian yang menyatakan ada pengaruh signifikan upah terhadap kesempatan kerja di Provinsi Jambi selama tahun 2000-2016. Artinya apabila terjadi peningkatan terhadap upah sebesar 1 persen maka akan mengakibatkan kesempatan kerja turun sebesar 0.335768 persen. Sesuai dengan pendapat Simanjuntak (2001) upah mempunyai pengaruh terhadap kesempatan kerja. Jika semakin tinggi tingkat upah yang ditetapkan, maka berpengaruh pada meningkatnya biaya produksi, akibatnya untuk melakukan efisiensi, perusahaan terpaksa melakukan pengurangan tenaga kerja yang berakibat pada rendahnya tingkat kesempatan kerja.

\section{KESIMPULAN DAN SARAN Kesimpulan}

Berdasarkan hasil analisis dan pembahasan yang telah dilakukan, maka dapat disimpulkan kesempatan kerja Provinsi Jambi selama periode tahun 2000 sampai 2016 bergerak secara fluktuatif dengan rata-rata pertumbuhan sebesar 3,11\%. Dengan pertumbuhan ekonomi rata-rata sebesar 6,23\%. Perkembangan investasi rata-rata tumbuh sebesar $13,97 \%$ setiap tahunnya. Belanja daerah tumbuh rata-rata sebesar $27,42 \%$ setiap tahunnya. Rata-rata perkembangan inflasi sebesar $1,16 \%$ setiap tahunnya. Dan perkembangan upah rata-rata sebesar $16,44 \%$ per tahun. Dari hasil regresi linear berganda diketahui bahwa investasi, belanja daerah dan upah berpengaruh signifikan terhadap kesempatan kerja Provinsi Jambi. Sedangkan pertumbuhan ekonomi dan inflasi tidak berpengaruh signifikan terhadap kesempatan kerja Provinsi Jambi. Elastisitas kesempatan kerja yang ada Provinsi Jambi selama mengalami fluktuasi pada 
setiap tahunnya. Jika dilihat secara keseluruhan maka besarnya elastisitas kesempatan kerja Provinsi Jambi yaitu sebesar 0,48, dari hasil ini dapat dikatakan bahwa kesempatan kerja bersifat InElastis $(\mathrm{E}>1)$.

\section{Saran}

Berdasarkan kesimpulan yang telah dikemukakan di atas maka saran-saran yang dapat diberikan oleh penulis di dalam penelitian ini adalah sebagai berikut Pemerintah harus berupaya mendorong investor untuk menanam modal lebih banyak pada industri padat karya serta mempermudah perizinan penanaman modal dan menyediakan infrastruktur yang menunjang terciptanya investasi. Dengan meningkatnya investasi diharapkan dapat tercipta kesempatan kerja baru bagi masyarakat. Pemerintah hendaknya terus mendorong pertumbuhan Produk Domestik Regional Bruto (PDRB) pada sektor yang banyak menyerap tenaga kerja serta meningkatkan kualitas sumber daya pada sektor yang berkaitan seperti sektor pertanian, perkebunan, pertambangan serta industri padat karya yang mampu menyerap banyak tenaga kerja. Pemerintah perlu meningkatkan belanja daerah yang berpihak terhadap masyarakat khususnya dalam sektor perekonomian melalui program-program yang mendorong masyarakat untuk menciptakan pekerjaannya sendiri dan bahkan untuk orang lain. Pemerintah harus berfokus untuk mengendalikan inflasi di Provinsi Jambi, apabila inflasi dalam kondisi yang stabil dapat mendorong investor untuk menanamkan modalnya. Sehingga mampu mendorong terciptanya kesempatan kerja baru. Pemerintah sebaiknya berfokus kepada nilai upah dengan tepat untuk meningkatkan kehidupan yang lebih layak khususnya bagi pagi para pekerja tetapi juga tanpa merugikan kelangsungan hidup perusahaan.

\section{DAFTAR PUSTAKA}

Amir, Amri., Junaidi., Yulmardi. (2009). Metodologi Penelitian Ekonomi dan Penerapannya. IPB Press: Bogor.

Badan Pusat Statistik (BPS). (2018). Investasi Provinsi Jambi Tahun 2000-2016. BPS Provinsi Jambi. BPS: Jambi.

Badan Pusat Statistik (BPS). (2018). Realisasi Belanja Daerah Provinsi Jambi Tahun 2000-2016. BPS Provinsi Jambi. BPS: Jambi.

Badan Pusat Statistik (BPS). (2018). Inflasi Kota Jambi Tahun 2000-2016. BPS Provinsi Jambi. BPS: Jambi.

Halim, Abdul (2003). Pengaruh Dana Alokasi Umum dan Pendapatan Asli Daerah Terhadap Belanja Daerah : Studi Kasus Kabupaten dan Kota di Jawa dan Bali. Bali.

Jhingan, M.L. (2004). Ekonomi Pembangunan dan Perekonomian. PT. Raya Grafindo Persada: Jakarta.

Mankiw, N. Greogory. (2007). Makroekonomi. Edisi Keenam. Erlangga: Jakarta.

Nainggolan, Indra. (2009). Analisis Faktor Yang Mempengaruhi Kesempatan Kerja Pada Kabupaten/Kota Di Provinsi Sumatera Utara. Medan: Badan Penerbit Universitas Sumatera Utara Medan. Diakses 24 September 2018.

Simanjuntak, P.J. (2001). Pengantar Ekonomi Sumber Daya Manusia. LPFEUL: Jakarta.

Sukirno, Sadono. (2010). Pengantar Teori Ekonomi Makro edisi Ketiga. Rajawali Press: Jakarta.

Tambunan, Tulus T.H. (2001). Transformasi Ekonomi di Indonesia. Salemba Empat: Jakarta. 